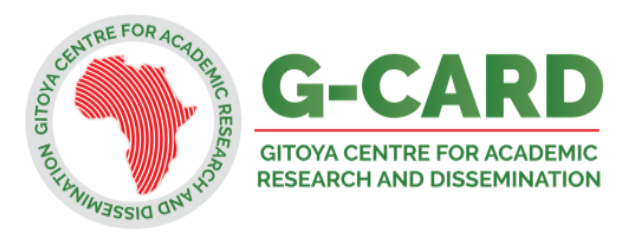

\title{
Effectiveness of the Strategic Planning and Academic Performance among the Public Secondary Schools in Babati District, Tanzania
}

\author{
Peter Kwaslema and Daniel Onyango, PhD \\ Saint Augustine University of Tanzania
}

Corresponding Email: jumadan06@gmail.com

\begin{abstract}
This study sought to establish teachers' perception on the schools' effectiveness in the development of the strategic plan, the perception of teachers on how the implementation of the strategic plan affects the academic performance and what should be done to ensure an effective strategic planning. The study used a mixed research approach while employing the convergent parallel design. The study population consisted of 2,844 stakeholders from 5 sampled schools whereby 185 respondents were drawn. The study concluded that there was effectiveness in the development of the Strategic Plan; the implementation of the strategic plan contributed to improved academic performance and various strategies were used by heads of schools to ensure that strategic plans were implemented. The study recommends that to be more effective in developing strategic plans, heads of schools should involve all stakeholders and hire experts to facilitate strategy formulations. Secondly, school heads should educate the school communities about benefits derived from effective implementation of strategic plans so that they can fully be committed to its implementation. Finally, school heads should come up with new strategies that will minimize resistance by school community members so as to speed up adoption as opposed to being pushed all the time by heads of schools in order for them to comply.
\end{abstract}

Key word: Effectiveness, Strategic Planning, Administrative Skills, Academic Performance

\section{Introduction}

Administrative skills are essential for leaders to manage school activities effectively. Through the administrative skills, heads of schools understand the factors that should be put in place for effective implementation of the school curriculum. According to Ndayor and Nkechi (2019), administrative skills in the context of educational institutions refer to the ability to skillfully and successfully plan, supervise, organize, coordinate, control, make decisions and initiate actions that would support and encourage teachers and students to realize schools goals. Therefore, heads of the schools need to employ the best administrative skills that would actualize school goals and objectives. The skills equip teachers and students with an impetus to work hard in achieving school goals and objectives.

Regarding the importance of utilization of appropriate administrative skills for students' academic performance, Jacobson (2011) states that school administrators need to believe in the ability of their students as they focus on improving the learning environment through constructively engaging teachers in a professional dialogue that leads to a participative instructional process. Administrators should therefore involve parents, community and other stakeholders in planning, designing and implementing school activities.

A study conducted in Malawi by Galafa (2018) emphasized that the administrative skills of the heads of schools positively influence the school development. In Tanzania, Mgani (2013) stated that strong leadership is associated with high organizational development, teaching effectiveness, strong organizational culture and positive principalteachers relationship, more participation in decision making, high teacher aspiration and professionalism. Therefore, school managers and heads of schools have a great role to play in the supervision and provision of the desired leadership responsibilities for the achievement of quality education. Whereby the quality education is 
reflected in school performance, the achievement of the learners cannot be realized without a proper utilization of appropriate administrative skills (Firmina, 2015).

Studies conducted by different scholars such as, Okode (2013), Chimuka (2016), Koc and Celik (2015) have argued that there is a strong correlation between the utilization of the administrative skills by the school heads and the achievement of school goals. As such, the researchers in this study hypothesized that effective utilization of administrative skills is a guiding aspect that should lead towards school performance. This study, therefore, sought to establish:

1. To establish teachers' perception on the schools' effectiveness in the development of the Strategic Plan.

2. To establish the perception of teachers on how the implementation of the strategic plan affects the academic performance.

3. To establish what should be done to ensure an effective strategic planning.

This study informs education stakeholders on the effectiveness of utilization of administrative skills in schools under investigation

\section{Theoretical Underpinnings}

The study was anchored on the Administrative Management Theory by Henri Fayol. This theory explains principles of management that are of importance in the utilization of administrative skills in a school setting. Some of these principles include: division of labor, principle of authority, discipline, unity of command, unity of direction, the subordination of individual interests to organizational interests, remuneration, order, equity, the stability of tenure, initiatives and the spirit of cooperation (Godwin, Handsome \& Ayomide, 2017). These principles direct an administrator on the right path to follow in attaining the desired school goals and objectives.

\section{Research Methodology}

This section presents the methodology of the study. it includes such aspects like the research design, population and sampling procedures, instruments, validation and the statistical treatment of data.

\section{Research Design}

The study employed the convergent parallel research design under the mixed method approach. As Creswell (2012) argues, by using the mixed research approach, the researcher is able to simultaneously collect both quantitative and qualitative data in order to gain an in-depth understanding of the study phenomenon.

\section{Population and Sampling}

The study was conducted among the 12 public secondary schools in Babati District from which 5 were randomly sampled. The targeted population in this study was 2844 stakeholders including 2453 students, 8 Ward Education Officers, the District Education Officer and 382 teachers. The researchers used the formula to determine the sample of 185 respondents. The sample included one District Education Officer, four Ward Education Officers, five school heads, eighty teachers, and ninety five students. The District Education Officer, Ward Educational Officer and Heads of Secondary Schools were purposively sampled while stratified random and simple random sampling techniques were used to sample teachers and students.

\section{Research Instruments}

This study used interview guides and questionnaires to collect data. Interview guides were used to get narrative clarifications from the District Education Officer, Ward Education Officers and Heads of Secondary Schools in relation to the study objectives. On the other hand, a questionnaire with both closed and open ended items was used to get numerical and quantifiable data from the students and teachers concerning the study objectives.

\section{Validity and Reliability}

The validity of the instruments was determined by research experts at the Saint Augustine University of Tanzania. The study employed split-half reliability method which was designed to correlate half of the items with the other half in the questionnaire. The scores that were obtained were calculated by using Spearman rank coefficient, which yielded the acceptable reliability.

\section{Statistical Treatment of Data}

The qualitative data was recorded using a pen, a note book and with the help of a mobile phone audacity app. The qualitative data was analyzed thematically while the quantitative data was analyzed using descriptive statistics in terms of frequencies, percentages and means.

\section{Findings and Discussion}

This section presents the findings of the study which are presented by research objectives. 
Objective 1: To establish teachers' perception on the schools' effectiveness in the development of the Strategic Plan.

The first objective of the study sought to establish teachers' perception on the schools' effectiveness in the development of the Strategic Plan among the public secondary schools in the Babati District.
The results in table 1 shows that 98.7 percent of the respondents agreed that teachers are involved in formulating the strategic plans in schools while 1.3 percent disagreed with this statement. It is also worth noting that 97.3 percent of the respondents agreed that there are strategies used in implementing the strategic planning in schools while only 2.6 percent disagreed.

Table 1: Teachers' Perception on Effectiveness in the Development of the Strategic Plan

\begin{tabular}{|c|c|c|c|c|c|c|c|c|}
\hline \multirow[t]{2}{*}{ Items in the Questionnaire } & \multicolumn{2}{|c|}{$\begin{array}{l}\text { Strongly } \\
\text { Agree }\end{array}$} & \multicolumn{2}{|c|}{ Agree } & \multicolumn{2}{|c|}{ Disagree } & \multicolumn{2}{|c|}{$\begin{array}{l}\text { Strongly } \\
\text { Disagree }\end{array}$} \\
\hline & $\mathrm{f}$ & $\%$ & $f$ & $\%$ & $f$ & $\%$ & $\mathrm{f}$ & $\%$ \\
\hline There is involvement of teachers in formulating the strategic plan & 31 & 40.8 & 44 & 57.9 & 1 & 1.3 & - & - \\
\hline There are strategies used in implementing the strategic plan & 33 & 43.4 & 41 & 53.9 & 2 & 2.6 & - & - \\
\hline There are resources that help in implementing the strategic plan & 19 & 25 & 51 & 67.1 & 5 & 6.6 & 1 & 1.3 \\
\hline Teachers are committed to implement the strategic plan & 42 & 55.3 & 33 & 43.4 & 1 & 1.3 & - & - \\
\hline There are resources that help in implementing strategic plans & 62 & 65.3 & 31 & 32.6 & 2 & 2.1 & & \\
\hline Teachers communicate school mission and vision & 70 & 73.7 & 19 & 20 & 4 & 4.2 & 2 & 2.1 \\
\hline
\end{tabular}

Table 2: Perceived Effect of the Strategic Plan on Academic Performance

\begin{tabular}{lcc}
\hline \multicolumn{1}{c}{ Items in the Questionnaire } & $\mathbf{f}$ & $\%$ \\
\hline It motivates school community to work hard as a team & 34 & 44.7 \\
It provides direction which leads to good academic performance by schools & 25 & 32.9 \\
Creates a commitment to work within school community & 17 & 22.4 \\
\hline
\end{tabular}

The Table further shows that 92.1 percent of the respondents agreed that there are resources which are identified to be used in implementing the strategic plans while 7.9 percent disagreed with the statement. Moreover, the findings in the table show that 98.7 percent of the respondents agreed that teachers are committed in implementing the strategic plans while 1.3 percent disagreed with the statement. Furthermore, $97.9 \%$ of the respondents agreed that resources are enough in implementing strategic plans while $(2.1 \%$ of the respondents disagreed. Finally, $93.7 \%$ of the respondents agreed that teachers communicate the mission and vision of the school to their students while $6.3 \%$ of the respondents disagreed on the statement. According to Okode, (2013), strategic planning shapes the direction towards which a school focuses its attention, resources and energy as well as giving room for adjustments for the future by continuously adjusting to an academic direction in response to changing academic situations.

Findings in response to the first research objective showed that teachers were involved in formulating and implementing the strategic plan. This implied that there exists a commendable working relationship and cooperation between school administration and the teachers. As such, school administrators should work hand in hand with school stakeholders to ensure that individual goals are aligned to the school goals and objectives.

On the other hand, teachers desired administrators who are honest, communicative, participatory and supportive (Mark, 2015; Amadi, 2008).

Objective 2: To establish the perception of teachers on how the implementation of the strategic plan affects the academic performance.

The second objective of the study sought to establish how the implementation of the strategic plan affects the academic performance as shown in table 2 where 76 teachers responded.

Table 2 shows that 44.7 percent of teachers stated that the strategic plan is a motivating factor for school community members to work hard as a team. Furthermore, 32.9 percent of the teachers stated that the strategic plan gives direction which leads to a good academic performance by the schools. On the other hand, 22.4 percent of the teachers stated that the strategic plan creates commitment to work. This is due to the reason that the formulated plans help teachers and students to be committed to teaching and learning process toward a specific target. As revealed by Okode (2013), a strategic plan in a school system gives a focus and direction for the 
future by continuously guiding toward a specific direction.

The qualitative data provided the findings that school leaders need to ensure that the school work hard toward a specific direction as specified in the strategic plans as follows:

Every school member should work according to the duty provided. The school administrator should ensure that all required teaching and learning materials are provided on time, teachers should provide an education which meets the needs of the students and students should study hard. This guarantees the fulfillment of the specified plans that are made in the school.

Objective 3: To establish what should be done to ensure an effective strategic planning.

The third objective sought to solicit ideas from teachers on what can be done to ensure an effective strategic planning as reflected on Table 3.

Table 3: What to do to Ensure an Effective Strategic Planning

\begin{tabular}{lcc}
\hline Items & $\mathbf{f}$ & \% \\
\hline Creating a good relationship among school members & 24 & 31.6 \\
Encourage commitment & 22 & 28.9 \\
Providing teaching and learning materials & 19 & 25 \\
Conducting regular follow-ups of strategic plans & 11 & 14.5 \\
\hline
\end{tabular}

The findings in table 3 show that among the 76 teachers, 31.6 percent commented that creating a good relationship among school members is the best way to ensure an effective strategic planning. Furthermore, 28.9 percent suggested that encouraging commitment to work would foster an effective strategic planning. The table further indicates that 25 percent of the respondents said that providing enough teaching and learning materials would contribute toward an effective strategic planning while 14.5 percent said conducting regular follow ups of the strategic plan would help schools to realize an effective strategic planning.

\section{Conclusions and Recommendations}

This section presents the conclusions and the recommendations of the study.

\section{Conclusions}

The study concludes that there is effectiveness in the development of strategic plans in schools under investigation. Stakeholders are involved in the process and this enhances ownership. It is also concluded that the implementation of strategic plans affected the academic performance of the secondary schools as it motivates, provides direction and creates commitment among the schools. Finally, it is concluded that various strategies such as followups were used by heads to motivate compliance in enhancing the strategic planning.

\section{Recommendations}

To be more effective in developing strategic plans, heads of schools should involve all stakeholders and hire experts to facilitate strategy formulations. Secondly, school heads should educate the school communities about benefits derived from effective implementation of strategic plans so that they can fully be committed to its implementation. Finally, school heads should come up with new strategies that will minimize resistance by school community members so as to speed up adoption as opposed to being pushed all the time by heads of schools in order for them to comply.

\section{Reference}

Amadi, E. C. (2008). Introduction to educational administration: a module. Nigeria: Harey Publications.

Chimuka, R. (2016). Effects of the School Strategic Plan on Pupils' Academic Performance in Selected Secondary Schools of Lundazi District, Zambia. Unpublished research Master degree. The University of Zambia.

Creswell, J. W. (2012). Educational research: planning, conducting, and evaluating quantitative and qualitative research (4th ed). Boston: Pearson.

Firmina, S. R. (2015). The Impact of the Leadership and Management on Academic performance in Secondary Schools in Tanzania. The case of Iringa Region (Doctoral dissertation, The Open University of Tanzania).

Galafa, B. (2018). Challenges to educational administration and management in primary 
schools in Malawi. North American Academic Research, 1 (2), 1-14.

Godwin, A., Handsome, O. E. \& Ayomide, W. A. (2017). Application of the Henri Fayol principles of management in startup organizations. IOSR Journal of Business and Management, 19 (10), 78-85.

Jacobson, S. (2011). Leadership effects on students achievement and sustained school success. International Journal of Educational Management, 25 (1), 33-44.

Koc, N. \& Celik, B. (2015). The impact of number of students per teacher on students' achievement. Procedia-Social and Behavioral Science, 177, 65-70. Doi: 10.1016/j.sbspro.2015.02.335.

Mark, A. (2015). Factors influencing teachers' motivation and job performance in Kibaha district, Tanzania. Master Degree. Open University of Tanzania.

Mgani, V. D. (2013). Leadership styles and school functioning: The case of Kilosa District secondary schools. (Master's degree). Open University of Tanzania.

Ndayor, G. C. B. \& Nkechi, O. F. (2019). Principals' managerial skills and teachers' job performance in public secondary schools in rivers state, Nigeria. International Journal of Innovative Psychology and Social Development, 7 (2), 97-104.

Okode, G. O. (2013). Influence of Secondary Schools' Strategic Planning on Students' Academic Performance in Rachuonyo North District, Kenya. Unpublished research master's degree. University of Nairobi. 